\title{
Miranda
}

Revue pluridisciplinaire du monde anglophone /

Multidisciplinary peer-reviewed journal on the English-

speaking world

19 | 2019

Rethinking Laughter in Contemporary Anglophone Theatre

\section{The Snapper by Roddy Doyle and Alys, Always by Lucinda Coxon}

Performance Review

\section{William C. Boles}

\section{(2) OpenEdition}

\section{Journals}

Electronic version

URL: http://journals.openedition.org/miranda/21105

DOI: $10.4000 /$ miranda. 21105

ISSN: 2108-6559

\section{Publisher}

Université Toulouse - Jean Jaurès

\section{Printed version}

Date of publication: 7 October 2019

\section{Electronic reference}

William C. Boles, "The Snapper by Roddy Doyle and Alys, Always by Lucinda Coxon", Miranda [Online]

19 | 2019, Online since 11 October 2019, connection on 16 February 2021. URL: http://

journals.openedition.org/miranda/21105; DOI: https://doi.org/10.4000/miranda.21105

This text was automatically generated on 16 February 2021

\section{(c) (†) $\odot$}

Miranda is licensed under a Creative Commons Attribution-NonCommercial-NoDerivatives 4.0 International License. 


\section{The Snapper by Roddy Doyle and Alys, Always by Lucinda Coxon}

Performance Review

William C. Boles

\section{Factual information about the shows}

1 The Snapper by Roddy Doyle (adapted from his novel)--The Gate Theatre (Dublin) June 26, 2019

2 Director: Róisín McBrinn

Set \& Costume Designer: Paul Wills

Lighting Design: Paul Keogan

Sound Design: Sinéad Diskin

Choreographer: Paula O’Reilly

Video Design: Conan McIvor

Cast: Niamh Branigan, Hazel Clifford, Simon Delaney, Hilda Fay, Lauren Larkin, Simon O'Gorman, Carmel Stephens, Amilia Stewart, Luke Fitzgerald, David Murray, Lilymai Clancy, Molly McCarthy, Jayna McCloskey, Ellie Mooney, Emer Ryan, and Alannah Prendergast 
Fig. 1

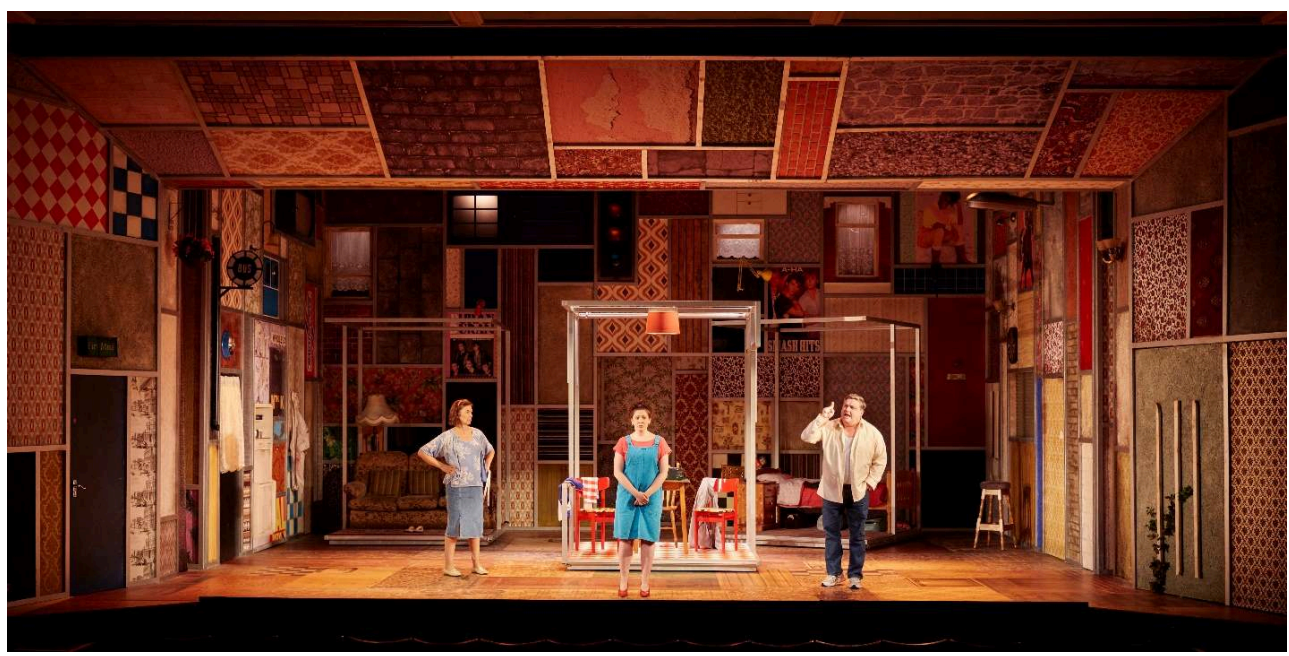

(L-R) Hilda Fay (Veronica), Hazel Clifford (Sharon), and Simon Delaney (Jimmy).

Photo credit: Ros Kavanagh

Fig. 2

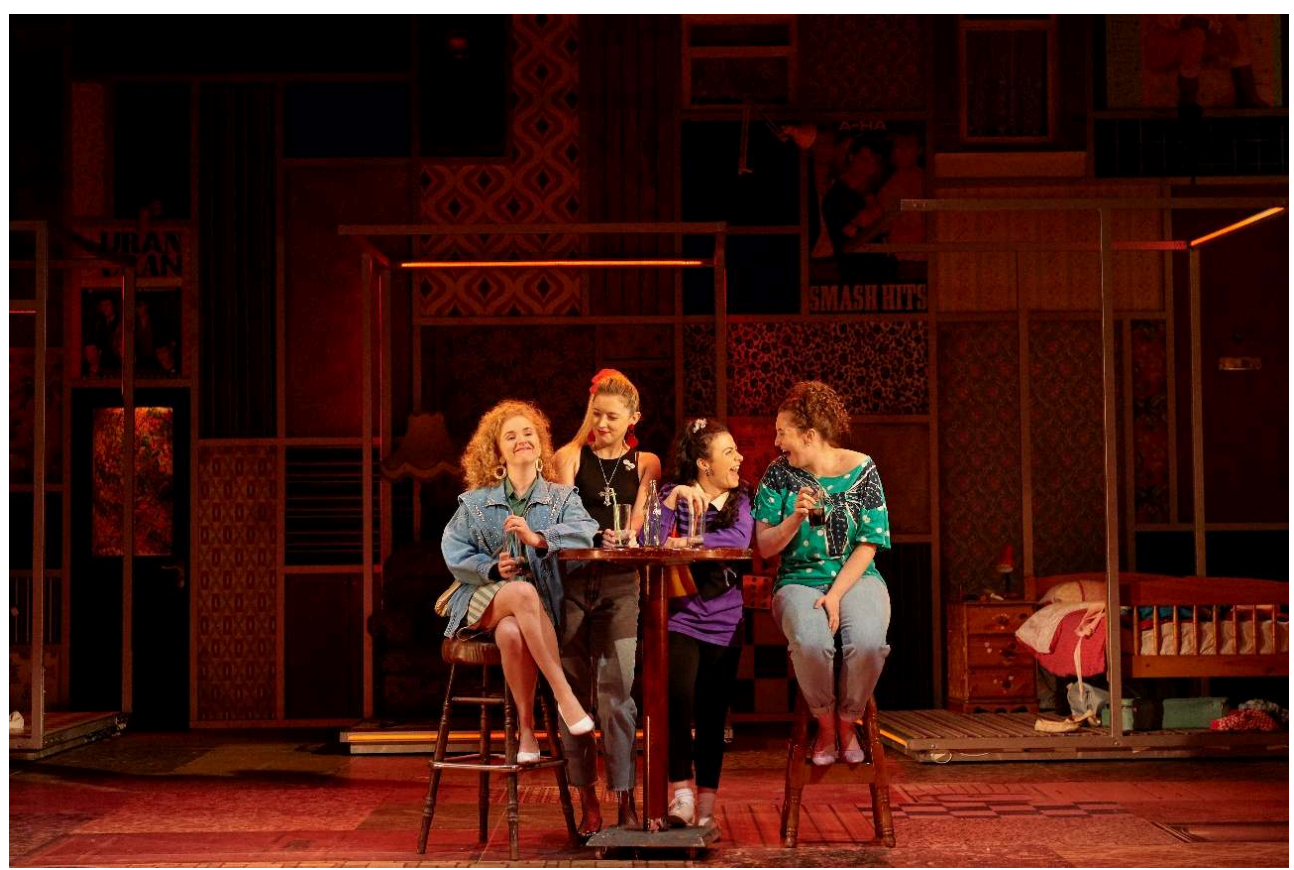

(L-R) Lauren Larkin (Jackie), Niamh Branigan (Yvonne), Amilia Stewart (Mary), and Hazel Clifford (Sharon).

Photo credit: Ros Kavanagh.

3 Alys, Always by Lucinda Coxon (adapted for the stage from Harriet Lane's novel)--The Bridge Theatre (London) March 5, 2019

4 Director: Nicholas Hytner

Production Designer: Bob Crowley

Costume Designer: Christina Cunningham

Composer: Grant Olding

Lighting Designer: Jon Clark 
Sound Designer: Gareth Fry

Cast: Joanna Froggatt, Joanna David, Vineeta Rishi, Simon Manyonda, Sylvestra Le Touzel, Danny Ashok, Robert Glenister, Leah Gayer, Sam Woolf, Sue Wallace, Jeff Rawle, and Maddie Cutter

Fig.3

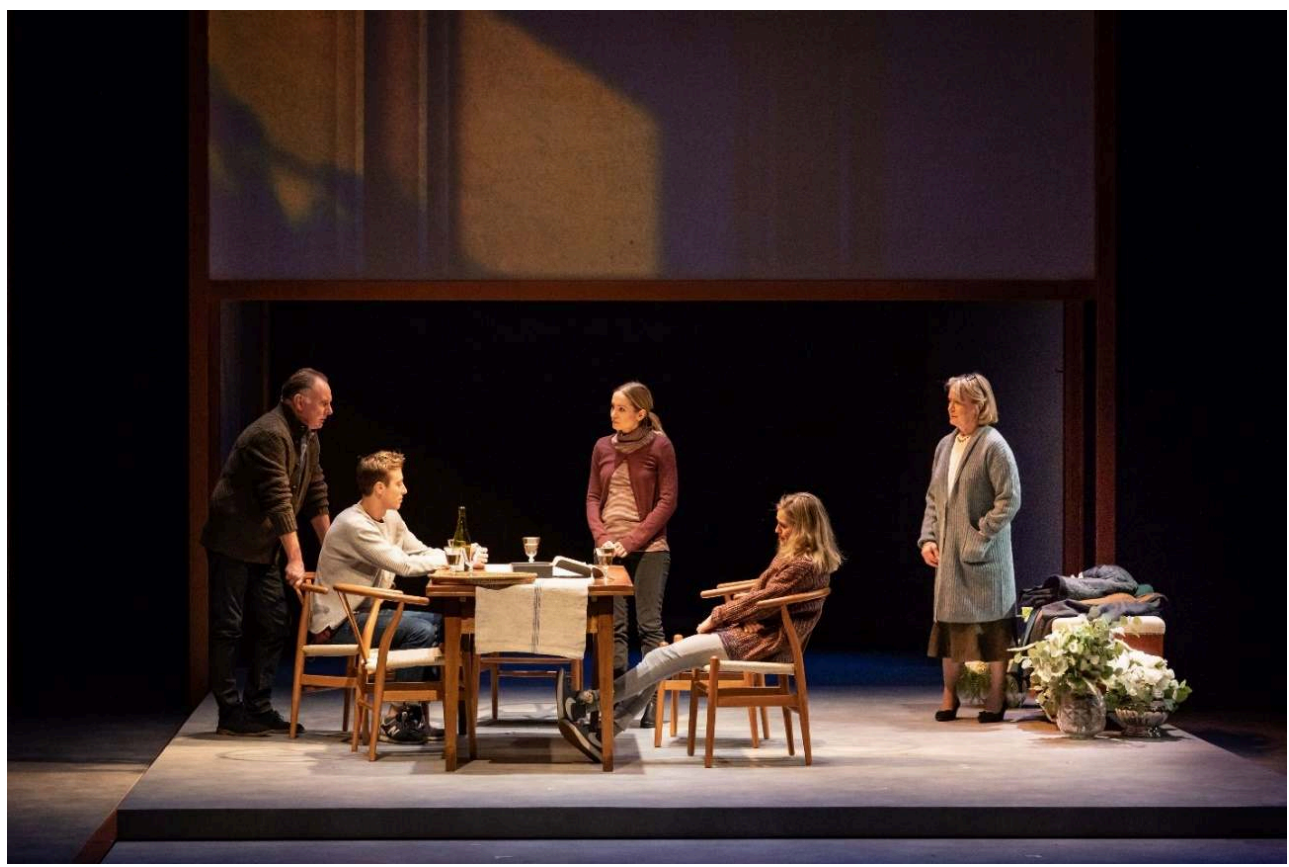

(L-R) Robert Glenister (Laurence), Sam Woolf (Teddy), Joanne Froggatt (Frances), Leah Gayer (Polly), and Joanna David (Charlotte).

Photo Credit: Helen Maybanks 
Fig.4

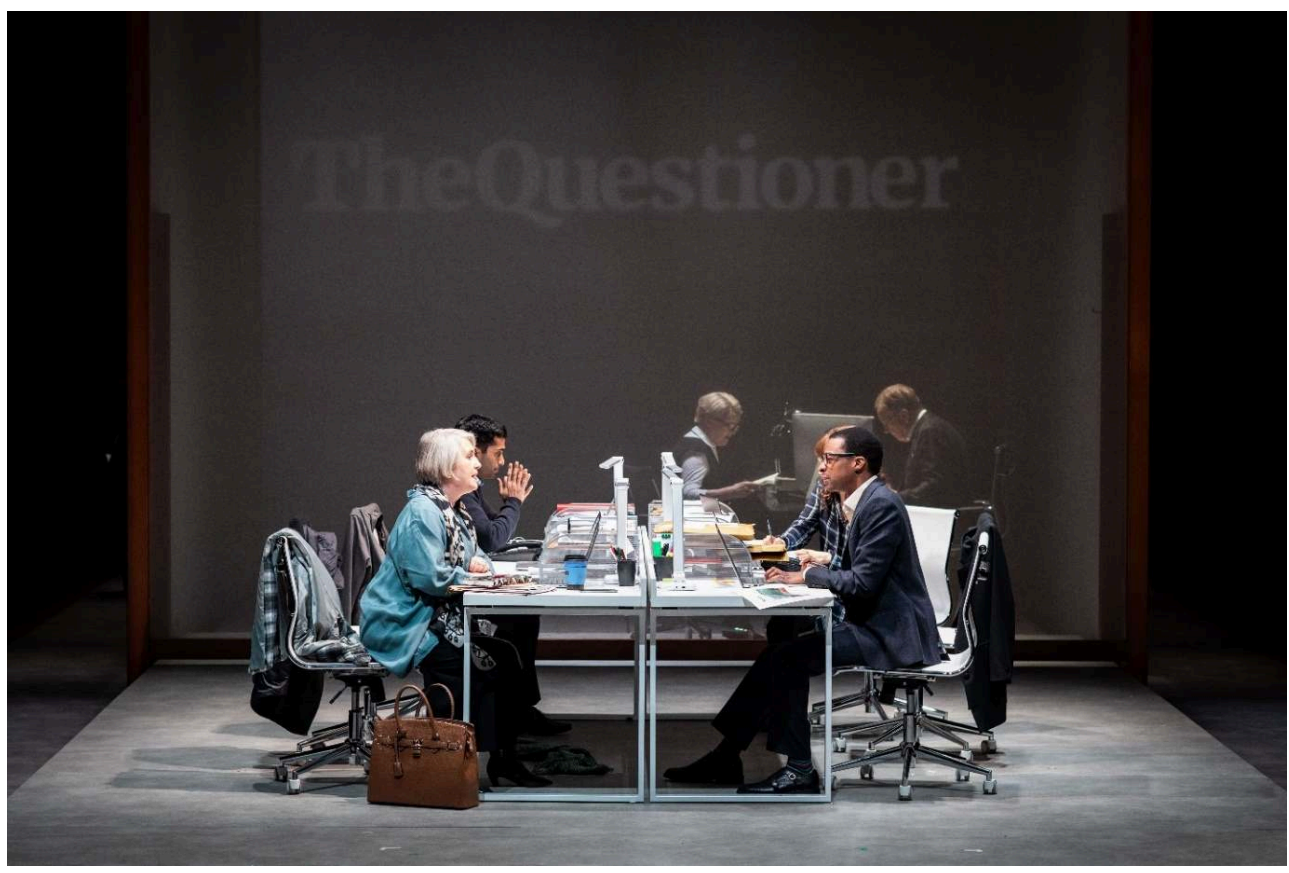

(Foreground L-R) Sylvestra Le Touzel (Mary), Danny Ashok (Sid) and Simon Manyonda (Oliver).

Photo Credit: Helen Maybanks

\section{REVIEW}

In doing press for his play Unreachable in 2016, Anthony Neilson summed up his perspective on the current state of the West End theatre, noting "There's still something very unimaginative about what's going on in the West End. In mainstream theatre, the model is: take a property based on [something by] someone else that was popular, put a celebrity of some sort into it, package it and send it out there. That's very stultifying." ${ }^{1}$ Three years later Neilson would no doubt find that his description still remains accurate about the plays being produced in London. Just a quick glance over the 2019 theatrical season finds Ivo van Hove directing the stage adaptation of the 1950 film All About Eve, starring Gillian Anderson and Lily James; The Man in the White Suit, adapted from the Ealing Studios' 1951 film, which stars Stephen Mangan in the Alec Guinness role, continues to play on the West End as I write this piece; and coming in November to the National Theatre is the stage adaptation of Elana Ferrante's novel My Brilliant Friend (adapted by April De Angelis), which will star Niamh Cusack and Catherine McCormack and is slated to fill the same slot as past, big budget Olivier Theatre holiday offerings, such as War Horse, His Dark Materials, Nation, and Treasure Island. While Neilson referred to the West End, his comment has some applicability to a recent critically and financially successful production at Dublin's Gate Theatre. My interest here then is applying Neilson's dictum to two recent productions of previous non-theatrical properties: the Bridge Theatre's production of Alys, Always, adapted by Lucinda Coxon from the highly successful novel by Harriet Lane, and the Gate Theatre's production of The Snapper, adapted by Roddy Doyle from his own work. 
7 Of the two productions under consideration here perhaps the most representative of Neilson's deprecating comment about the West End's over reliance on adapting properties can be found in the Bridge Theatre's decision to commission Lucinda Coxon to adapt the popular novel Alys, Always (2012) as the follow-up production to the timebending, rambunctious, literary history exploding Martin McDonagh play A Very Dark Matter. Harriet Lane's successful debut novel offered a cagey and subtly unreliable female narrator through Frances, the literary minded main character, who differs sharply from the plethora of unreliable, usually heavy drinking or medicated, introverted, depressed, self-doubting female narrators that would shortly follow, best represented by Paula Hawkins' The Girl on the Train (2015). The premise of Lane's story is that Frances, by virtue of being first on the scene of a car accident, is the only witness to the death of Alys Kyte, who turns out to be the wife of the famous novelist Laurence Kyte. Frances is drawn into the orbit of the grieving Kyte family when they want to meet the last person to see Alys before she died. Building upon that meeting with the family and her subsequent attendance at the funeral, Frances becomes confidante to Polly, the Kyte daughter, and soon finds herself on the guest list to stay at the Kyte country home, where she catches the eye of Laurence and eventually enters into a romantic relationship with him. By the end of the novel (and the play) through a devious manipulation of an intimate situation between them, Frances ends up marrying him and it is suggested that she will now become a strong directive, editorial voice behind his novels. A contributing motivation to her involvement with the Kyte family stems from the fact that she works for a literary section of a slowly failing newspaper and while bettering herself socially through her relationship with the Kytes, she also betters herself professionally as she ascends up the editorial ladder using her relationship with Laurence as her tool of advancement.

8 As Neilson noted, the production relied heavily not only on the familiarity of the audience with Lane's novel, but also the prominent display of Joanna Froggatt throughout all of its publicity for the play. As one of the more recognizable stars of Downton Abbey (in real life she looks just like she does on the show, unlike some of the other actresses who are not as easily identifiable outside of their early twentiethcentury costumes and wigs), Froggatt was featured prominently in the advertising campaign as she stared out surprised from the theatre poster, aiming to bring in potential punters, who would recognize the Downtown star and be drawn to see her in person on stage. The casting of Froggatt was inspired because Frances is a bit mousy (personality and appearance wise) at the story's start, but as she rises through work and social circles, she gains self-confidence about her appearance and her interactions with others, which parallels perfectly the character arc of Anna Bates, the character Froggatt played for the seven series (and now a movie).

9 One can understand then why the Bridge was drawn to this project. They choose a successful female written and oriented best seller; the main character, who is onstage almost entirely throughout the play, is a plum female role for an actor and, thus, attractive to a star caliber performer; and Coxon has successfully adapted material for the stage, television and film, including penning the Oscar-winning, Eddie Redmayne vehicle The Danish Girl. Despite all these elements, the production was not a staggering hit, but neither was it a flop. London reviewers found the play to be a moderately successful piece, but not a game changer, not one that needed to transfer to the West End for a longer run, and not a production that was all that memorable once one left 
the theatre. As for me, not being familiar with the novel prior to seeing the show, I found the production and story to be incredibly static, which I later discovered is actually part of the novel's narrative device, as it incrementally builds up to the shocking action taken by Frances to cement her position with Laurence and eventually ensnare him in marriage. Lane's novel is also short, only a slight bit over 200 pages, so the incremental movements work within the limited length of the story. However, Lane's plotting when moved to the stage becomes stagnant. The upward mobility of Frances at work and in the Kyte social circle moves far too slowly, making for a theatrical experience that was far from engaging. Perhaps best representative of the play's lack of dramatic intensity occurred when Frances' decision to go to the Kyte home for a long weekend is the culminating action that brings the first act to a close, which really is not a plot point that would excite an audience to return expectantly from the lobby bar to see what happens next.

10 I will admit, though, that my seat for the performance, which was opening night, was in the last row of the entire auditorium, which no doubt may have colored my reaction to the seemingly lack of movement of the play. From my perch it was impossible to connect with the characters and story. No doubt, the subtle interplay between the characters were lost on those of us in the back (and this is a story reliant on small moments, which carry great significance), but they would have been appreciated by those audience members closer to the stage. As I left the theatre that night, it struck me that the play might have worked better in a far more intimate space than the Bridge. I could see it succeeding in spaces the size of the Dorfman Theatre, Trafalgar Studios 1, or the Young Vic, which would allow the entire audience to engage with Frances and her disruptive, self-motivated journey into the domination of a grieving Kyte family, but, of course, such a production, offered in an Off-West End house would run counter to the way theatre in London works, and the Bridge Theatre is definitely interested in star-casting when it comes to their productions (whether an adaptation, new plays, or revival).

11 The Gate Theatre in Dublin would also be a perfect sized space to engage with the domestic and professional journey of Frances, and the intimate size of the theatre's space is perhaps one of the reasons why The Snapper's initial theatrical production segued into a tour of Ireland and then a return engagement to the theatre where it all started. My inclusion of Roddy Doyle's The Snapper in this discussion might not, upon first glance, appear to hew to the description that Neilson laid out above, since in this case the novelist is adapting his own material for the stage and the actors in the production do not have the same international name recognition as the actors who appear in West End adaptations. However, at the same time the Gate commissioning Doyle in 2018 to adapt The Snapper for the stage is a clear echo of Neilson's view that theatre is "unimaginatively" looking for new product to be produced on the stage by relying on material from other mediums. The decision to have Doyle adapt the second book in his Tarrytown trilogy (The Commitments and The Van round out the other two volumes) would be considered by many to be an incredibly safe commercial bet, since Doyle is a much loved figure in Ireland, his trilogy has been critically lauded, and each novel has been made into a film, each featuring Colm Meaney as the put upon father. Plus, The Commitments had already been adapted by Doyle in 2014 as a West End musical that opened at the Palace Theatre. So, perhaps, in this case applying Neilson's theory to this production, the star of the production was not a cast member but Doyle himself instead. Testifying to Doyle's theatrical acclaim, the night that I saw The Snapper at the 
Gate, his latest play Two Pints, drawn from a collection of dialogue pieces he had written on his Facebook page, was having its opening night just a few blocks away at The Abbey Theatre.

12 In comparing The Snapper to Alys, Always, there are automatically some elements in favor of The Snapper that aids in its moving to the stage. The Gate Theatre itself is, in comparison to the Bridge, a far more cozy and intimate space, providing a perfect opportunity for the audience to connect with the Rabbitte clan. Clearly, having the author of the original work do the adaptation provides for a much more fluid experience (especially when it comes to changing the novel to the stage, seen by his changing of the number of children the family has to make it more economical on the stage) as well as the fact this version is the third iteration Doyle has written of the characters. In addition, the Rabbitte family is a comfortable, familiar, enjoyable part of contemporary Irish culture and this fondness became apparent prior to the start of the show because the energy level of the audience was much higher than what I have experienced in West End and Broadway theatres, and the fact that it was a Wednesday night made it even more surprising. From the first minutes of Sharon's opening monologue realizing that she was pregnant, the audience responded with warmth, laughter and enjoyment as they comfortably returned to the Rabbitte family and their humorous struggles from the twin daughters enrolling in a dance competition (forcing their mother to relentlessly sew sequins on their dresses) to the son's desire for a bicycle for his birthday and his subsequent crashes to Jimmy trying to find something to watch on television to the family and town drama surrounding Sharon's pregnancy and her refusal to name the "fella" who got her pregnant. It is worth noting for those not familiar with Dublin, that there was an extra familiarity between the playgoers, the play, and its performance at the Gate Theatre. At the end of the play when Sharon gives birth (and a real baby makes an appearance in this scene much to the fluttering and cooing of the audience as well as a loud ovation when its mother collected her child during the curtain call), it is in the same hospital that abuts the Gate Theatre, the one the audience sees from the lobby bar windows, making the piece feel even more closely connected to the theatre and the community attending it.

13 Based on the success Doyle has had with all of the iterations of the Tarrytown trilogy, it would not be surprising to see Doyle adapting the last novel in the series The Van for the stage, thus completing a trilogy trifecta (novel, film and play versions). Clearly, while Anthony Neilson, who likes to formulate his scripts through rehearsals with his actors, has an issue with the current state of the theatre relying on recycling previous material for the stage, the audiences have not yet had their fill. For theatres and artistic directors, successes like Simon Stephens' adaptation of Mark Haddon's The Curious Incident of the Dog in the Night-Time (probably the most successful play adaptation of the 2010s) and Doyle's The Snapper will encourage them to continue the practice, helping to alleviate the disappointment accompanying adaptations like Alys, Always. 


\section{NOTES}

1. Tim Auld, "Career suicide, or the role of a lifetime?" The Telegraph 3 July, 2016, https:// www.telegraph.co.uk/theatre/what-to-see/career-suicide-or-the-role-of-a-lifetime-matt-smithon-why-his-n/ (accessed 14 August, 2019).

\section{ABSTRACTS}

Theatre reviews of The Snapper by Roddy Doyle (adapted from his novel), directed by Róisín McBrinn (6 June 2019-24 August 2019, The Gate Theatre-Dublin) and Alys, Always by Lucinda Coxon (adapted from Harriet Lane's novel), directed by Nicholas Hytner (25 February 2019--30 March 2019, The Bridge Theatre-London).

Critiques de la pièce The Snapper de Roddy Doyle (adaptée de son roman), mise en scène de Róisín McBrinn (6 juin 2019 - 24 août 2019, The Gate Theatre - Dublin) et Alys, Always de Lucinda Coxon (adapté du roman d'Harriet Lane), mise en scène de Nicholas Hytner (25 février 2019 - 30 mars 2019, The Bridge Theatre - Londres).

\section{INDEX}

Keywords: adaptation, celebrity casting, performance space, British theatre, Irish theatre, Tarrytown trilogy

Subjects: Theater

Mots-clés: adapation, célébrité, espace de jeu, théâtre britanique, théâtre irlandais, trilogie de Tarrytown

\section{AUTHOR}

\section{WILLIAM C. BOLES}

Professor

Rollins College, Florida (USA)

wboles@rollins.edu 